\section{Giant cell arteritis}

Renatta Varma and Anil Patel remind us of the variability in presentation of giant cell arteritis (GCA). ${ }^{1}$ Another patient's story presents yet another pitfall in GCA diagnosis.

A 76 -year-old woman presented to the emergency department with right temporal "head pain." Her erythrocyte sedimentation rate was $65 \mathrm{~mm} / \mathrm{h}$. The diagnosis was "headache, rule out temporal arteritis." Prednisone, $40 \mathrm{mg}$ per day, was prescribed, and the patient was referred for follow-up examination. Four days later, the patient's tenderness to percussion over the right temporal area persisted, and I increased the prednisone dosage. A biopsy was performed 2 days later.

The biopsy results, available I week later, showed no evidence of GCA, so the ophthalmologic surgeon stopped the patient's prednisone. The patient returned to me 4 days later with increasing "head pain." We discussed the possibility of false-negative biopsy findings, and I prescribed prednisone again (and osteoporosis prophylaxis). A consultation was arranged with a rheumatologist who concurred with the diagnosis of biopsy-negative CGA and continued to treat the patient accordingly.

Although the only confirmatory test for GCA is a positive biopsy, nondiagnostic biopsy specimens do not exclude the diagnosis. It is commonly accepted that, because of the patchy involvement of the arteries, biopsies may be nondiagnostic in many patients. Thus, because biopsies are invasive, some authors even suggest that biopsy may not be necessary. ${ }^{2,3}$

Furthermore, corticosteroid therapy, which should be started without delay, rapidly reduces the chance of a positive biopsy result. ${ }^{2}$ One week of corticosteroid treatment may reduce the chance of obtaining a positive biopsy to 10\%. ${ }^{4}$ Therefore, biopsy should be performed within the first few days of therapy. ${ }^{4}$

Gary N. Fox

Defiance Clinic

Toledo, Ohio

\section{REFERENCES}

I. Varma R, Patel AD. Scalp lesions in a 78-year-old woman. CMAJ 2005;173(I):33.

2. Swannell AJ. Polymyalgia rheumatica and temporal arteritis: diagnosis and management. BMJ I997; 314:1329-32.

3. Caselli RJ, Hunder GG. Giant cell (temporal) arteritis. Neurol Clin I997;15:893-902.

4. Pountain G, Hazleman B. ABC of rheumatology. Polymyalgia rheumatica and giant cell arteritis. BMJ I995;310:1057-9.

Competing interests: None declared.

DOI:I0.1503/cmaj.1050155

Renatta Varma and Anil Patel recently discussed herpes zoster (varicella zoster virus) infection as a differential diagnosis of GCA. ${ }^{1}$ Interestingly, $88 \%$ of arteries with histologically confirmed GCA have been found to harbour herpes simplex virus DNA. ${ }^{2}$ Consideration of both herpes zoster and herpes simplex as a cause in this case of necrotic scalp lesions may therefore be warranted.

\section{Heike Varnholt}

Department of Pathology

Baystate Medical Center

Springfield, Mass.

\section{REFERENCES}

I. Varma R, Patel AD. Scalp lesions in a 78 -year-old woman. $C M A J$ 2005;173(I):33.

2. Powers JF, Bedri S, Hussein S, et al. High prevalence of herpes simplex virus DNA in temporal arteritis biopsy specimens. Am J Clin Pathol 2005;I23:26I-4.

DOI:I0.1503/cmaj.I050I6o

\section{[The authors respond:]}

We concur with Gary Fox that if the clinical suspicion of GCA is high this condition should still be considered even if the biopsy results are nondiagnostic, especially because of its potential to cause devastating bilateral and irreversible blindness. ${ }^{1}$ However, we would caution against diagnosing giant cell arteritis without biopsy evidence (biopsy-negative GCA) because of the potential detrimental side effects of long-term steroid use.

Skip lesions are possible, ${ }^{2,3}$ but we find it useful to obtain a biopsy specimen at least $2-3 \mathrm{~cm}$ long and to ensure that the pathologist serially examines the entire length of the specimen. If clinical suspicion remains despite a negative unilateral biopsy, then we recommend a contralateral biopsy as soon as possible, regardless of the time that has elapsed. Although steroid administration can affect a biopsy result, we have had numerous patients for whom a biopsy result was positive even after several weeks or months of steroid therapy. Furthermore, we consider temporal artery biopsy to be a relatively safe and simple office procedure. If 2 temporal artery biopsies are negative for GCA, we consult an internist to evaluate the patient's erythrocyte sedimentation rate or C-reactive protein level, or both, to search for a systemic infection or malignancy.

\section{Anil D. Patel}

Clinical Associate Professor

Dean A. McGee Eye Institute

Oklahoma City, Okla.

\section{Renatta Varma}

Fellow

Vitreoretinal Surgery

Victoria, BC

\section{REFERENCES}

I. Hayreh SS, Podhajsky PA, Zimmerman B. Ocular manifestations of giant cell arteritis. Am J Ophthalmol I998;125:509-20.

2. Klein RG, Campbell RJ, Hunder GG, et al. Skip lesions in temporal arteritis. Mayo Clin Proc 1976; 5I:504-IO.

3. Albert DM, Ruchman MC, Keltner JL. Skip areas in temporal arteritis. Arch Ophthalmol 1976;94:2072-7.

DOI:I0.1503/cmaj.I050197

\section{Corrections}

The DOIs for a recent commentary ${ }^{1}$ and a recent review article ${ }^{2}$ should have read I0.1503/cmaj.05I29I and $10.1503 / \mathrm{cmaj}$ .050I4I, respectively.

\section{REFERENCES}

I. Knoll G, Cockfield S, Blydt-Hansen T, et al, for the Kidney Transplant Working Group of the Canadian Society of Transplantation. Canadian Society of Transplantation consensus guidelines on eligibility for kidney transplantation CMAJ 2005;173 (Io):II8I-4.

2. Babuin L, Jaffe AS. Troponin: the biomarker of choice for the detection of cardiac injury. $C M A J$ 2005;I73(I0):II9I-202.

DOI:I0.I503/cmaj.051428 